\title{
With Gratitude
}

Books like this one are woven of the gifts others make of their time, knowledge, and sympathies. Some can be reciprocated. Others only acknowledged.

I have enjoyed institutional support from the University of Virginia, both in financial resources for research trips and time for writing. I am grateful for the opportunity in 2015 to give a series of papers through the UVa-École des Hautes Études en Sciences Sociales exchange program, which not only allowed me to present emerging ideas to the Séminaire de Recherches sur les Lumières, in Paris, but also enabled me to consult sources in the Bibliothèque Nationale. The invitation to present a keynote address at the summer 20I5 Territorio Guaraní International Workshop in Posadas, Argentina, was an honor and could not have come at a better time. A paper at the 2014 Jornada Internacional de Jesuitas in Buenos Aires gave me the chance to encounter the vital scholarly community around the missions and Jesuit studies during an early foray into new material.

Colleagues far afield have given of themselves over the years. I had the gift of some tough questions and sharp observations from linguist and anthropologist Bartomeu Melià, S.J. at the Guaraní workshop in Posadas 20I5. His enormous contributions to the field of Guaraní and mission studies are unsurpassed. He will be missed. Professor Guillermo Wilde and Professor Eduardo Neumann were welcoming in Buenos Aires and pushed me to keep going. Professor Tamar Herzog gave me the opportunity to present new ideas to a distinguished group of colleagues at 
Harvard in 20I5. Lic. Vicente Arrúa Ávalos, director of the Archivo Nacional de Asunción opened the archive to me with a generosity and spirit of collaboration I cannot hope to reciprocate fully. My conversations with Professor Capucine Boidin at Paris III and the Centre de Recherche et de Documentation sur les Amériques have been essential to my understanding and use of Guaraní sources. Her spectacular work, with colleagues involved with the Lenguas Generales de América del Sur project, especially the growing Guaraní corpus, is transformational. I hope to be able to return the gift someday. Professor Shawn Austin, at the University of Arkansas, helped crystallize critical issues regarding interactions between Guaraní and Spaniards in collegial conversations in Spain and Oaxaca. I benefited enormously from a close reading of the manuscript by Professor Julia Sarreal at Arizona State University. Professor John Tutino, at Georgetown, has followed the project for years. Our convergent concern for the histories of capitalism and modern economy have been powerfully generative. His reading of the manuscript and comments have been indispensable in helping me focus the larger argument.

There are as many to thank in Charlottesville. Librarian Miguel Valladares is the wizard of the bibliosphere. His capacity to conjure obscure sources, or just hard-to-get ones, from thin air never ceases to astound. The project would have taken much longer without his help. Fr. Michael Suárez, S.J., director of the Rare Book School at UVa, opened the doors to the Jesuit archives in Rome at an early stage in the research. Friends and colleagues have provided the heartening milieu essential to any sustained scholarly undertaking. Professor Herbert "Tico" Braun has shown that friendship and collaboration are measured in lifetimes. Professor Thomas Klubock generously read parts of the manuscript and offered incisive comments. Professor George Mentore and Professor Richard Handler helped me think about the difficulties and rewards of working at the seams between disciplines. I benefited immensely from a presentation at UVa's vibrant interdisciplinary Movements and Directions in Capitalism (MADCAP) working group. Graduate students Rachael GivensJohnson and Kimberly Hursh were patient at moments when it must have seemed our discussions had been hijacked by a preoccupation with my own project. Simran Budhwar and Aran Teeling took on the exacting work of helping me put the notes and bibliography into good order. Indexer Kate Mertes captured the spirit of the text. The fine people at Stanford University Press made an intricate process smooth and rewarding: 
editors Margo Irvin, Cindy Lim, and Emily Smith; marketing manager Stephanie Adams; copy editor Barbara Armentrout; cartographer Bill Nelson; and art director Rob Ehle. My friends, colleagues, and running crew Professor Paul Halliday, Steve Light, and Professor Christian McMillen listened and offered gentle advice through huffing and puffing. As he has throughout my scholarly life, my dad listened attentively, and gently asked the what-does-that-mean questions that helped me see where I was not making myself clear. My mom always knew it would get done, even when I was unsure. As ever, Bronwyn and Amanda gamely put up with the temporary insanity that accompanies these endeavors. Without their understanding there would be little point. 
This page intentionally left blank 
New World of Gain 
This page intentionally left blank 